\title{
Cell therapeutic approaches using multipotent mesenchymal stromal cells for muscular dys- trophy
}

\author{
Yuko Nitahara-Kasahara'), Shin'ichi Takeda') \\ and Takashi Okada ${ }^{1,2, *)}$
}

${ }^{1)}$ Department of Molecular Therapy, National Institute of Neuroscience, National Center of Neurology and Psychiatry, Tokyo, Japan

${ }^{2}$ Department of Biochemistry and Molecular Biology, Division of Gene Therapy Research, Center for Advanced Medical Technology, Nippon Medical School, Tokyo, Japan

Multipotent mesenchymal stromal cells (MSCs) have potential therapeutic uses owing to their ability to differentiate in situ into various cell types with immunosuppressive properties. Clinically, MSCs have been used to treat inflammatory diseases, such as steroid-resistant graft-versus-host disease. We previously reported a strategy to expand MSC cultures and to induce these cells to undergo myogenic differentiation, which is promising for the treatment of muscular diseases. Muscular dystrophy is an incurable genetic disease with early mortality and causes skeletal muscle weakness with chronic inflammation. Here, we focused on the beneficial properties of MSCs, namely, they can undergo mesoderm differentiation, have the ability to fuse with dystrophic muscles, and have anti-inflammatory activities. In this review, we highlight and discuss MSC-based therapeutic approaches for muscular dystrophy.

Rec.1/22/2014, Acc.9/12/2014, pp198-205

${ }^{*}$ Correspondence should be addressed to:

Takashi Okada, Department of Biochemistry and Molecular Biology, Division of Gene Therapy Research, Center for Advanced Medical Technology, Nippon Medical School, 1-1-5 Sendagi, Bunkyo-ku, Tokyo 113-8602, Japan. Phone: +81-3-3822-2131, Fax: +81-3-5814-8156, E-mail: t-okada@nms.ac.jp

Key words multipotent mesenchymal stromal cells, anti-inflammation, muscular dystrophy, muscular differentiation, cell transplantation

\section{Introduction}

Multipotent mesenchymal stromal cells (MSCs) from bone-marrow are conventionally defined as adherent non-hematopoietic cells that express several cell surface antigenic markers, such as CD44, CD73, CD90, and CD105, but not the hematopoietic markers CD34 or CD45 ${ }^{11}$. Although they were originally identified in bone-marrow ${ }^{1)}$, MSCs can be extracted from numerous tissues including 
adipose tissue ${ }^{2)}$, heart tissue ${ }^{3)}$, Wharton's jelly ${ }^{4)}$, dental pulp $^{5)}$, peripheral blood ${ }^{6)}$, cord blood ${ }^{7}$, menstrual blood ${ }^{8-10)}$, and fallopian tube tissue ${ }^{111}$. MSCs have been extensively studied owing to their ability to self-renew and differentiate into many different cell types in culture, particularly cells of mesodermal origin such as osteoblasts, chondrocytes, adipocytes, and myocytes ${ }^{12,13)}$. Furthermore, MSCs can also differentiate into cells of non-mesodermal origin, such as hepatocytes ${ }^{14,15)}$, neural cells ${ }^{16)}$, and epithelial cells ${ }^{17)}$. MSCs can influence immune effector cell development, maturation, and function, as well as alloreactive T-cell responses, through the production of bioactive cytokines and proteins ${ }^{18)}$. The multilineage potential of MSCs has been further exploited in their potential use as therapies for various diseases, which is feasible because these cells can be readily obtained from patients, are easily expanded in culture, and are not tumorigenic. Furthermore, the use of third-party MSCs in cell therapies is facilitated by the fact that these cells are immunoprivileged because they do not express human leukocyte antigen (HLA) class II proteins, $\mathrm{CD} 40, \mathrm{CD} 80$, or $\mathrm{CD} 86^{19)}$, and express only low levels of HLA class I proteins. Consequently, MSCs are not lysed by natural killer (NK) cells or cytotoxic T lymphocytes ${ }^{20}$.

Recently, MSCs have obtained market authorization as a product for the treatment of acute graft-versus-host disease (GVHD) in Canada and New Zealand. MSCs are being evaluated in Phase 3 clinical trials to treat Crohn's disease and acute radiation syndrome, and in Phase 2 trials to treat several ailments such as type I diabetes, acute myocardial infraction, and pulmonary disease (Mesoblast Inc., http:// www.mesoblast.com/products/overview). Furthermore, MSCs are extremely attractive candidates for cell-based strategies that target other diseases such as muscular disease ${ }^{21)}$. In this review, we discuss how MSC therapy might have beneficial effects on the progression of muscular dystrophy via eliciting anti-inflammatory effects and/or promoting the regeneration of myofibers.

\section{Myogenic differentiation of MSCs}

MSCs themselves can be induced to differentiate along the myogenic pathway, thereby fusing with myotubes and promoting the formation of new muscle fibers after being transplanted into muscle tissue ${ }^{22}$.

MSCs can form muscle cells after treatment with one or a combination of 5'-azacytidine (a demethylating agent), hydrocortisone ${ }^{23)}$, dexamethasone, ascorbic acid, and growth factors, when co-cultured with immortalized myoblast cells $(\mathrm{C} 2 \mathrm{C} 12)^{24,25)}$, or when exposed to the conditioned media of these cells ${ }^{26)}$. A method has been reported to induce skeletal muscle lineage cells from human and rat adherent MSCs via transduction with the Notch1 intracellular domain and administration of certain trophic factors and cytokines ${ }^{22}$. Upon genetic modification with a lentiviral vector encoding Pax3, which is the master regulator of the embryonic myogenic program, expression of myogenic regulatory factors is activated in human MSCs after 4 weeks of culture, suggesting that Pax 3 enables MSCs to differentiate into myogenic progenitors in vitro ${ }^{27)}$.

We have also reported efficient methods to expand MSC cultures obtained from dog bone-marrow and to induce the myogenic differentiation of these cells ${ }^{21)}$. CD271 is a marker of progenitor cells and bone-marrow-derived $\mathrm{MSCs}^{28)}$. MSC cultures enriched in CD271 ${ }^{+}$cells grow better than CD271-depleted cultures. Transduction of CD271 ${ }^{+}$MSCs with MyoD-expressing adenovirus vector, as an inducer of myogenic differentiation, causes the formation of myotubes that express late myogenic markers. These methods may be useful to efficiently transplant cells for the treatment of muscle disease.

\section{Paracrine effects of MSCs}

MSCs secrete distinctively different cytokines and chemokines, such as greater amounts of VEGF-a, IGF-1, EGF, keratinocyte growth factor, angiopoietin-1, stromal derived factor-1, macrophage inflammatory protein-1a and $\beta$ and erythropoietin ${ }^{29)}$. After transplantation, MSCs home to interstitial muscle tissue and localize close to satellite cells. MSCs induce the myogenic differentiation of neighboring satellite cells, as evidenced by the finding that isolated cells from muscle in which MSCs have engrafted show high myogenic activity and displayed CD45, sca-1;, Mac-1, CD34 ${ }^{+}, \mathrm{CXCR}^{+}, \beta 1$-integrin ${ }^{+}$characteristics $^{30}$. Clinical interest in the application of MSCs in cell therapies is not only owing to their ability to differentiate, but also to their release of cytokines into the surrounding environment, which modifies the developmental fate of neighboring cells in a paracrine manner.

\section{Cell therapeutic approach for muscular dystrophy}

In this section, we discuss whether the myogenic differentiation of MSCs beneficially affects the progression of muscular dystrophy. Muscular dystrophy patients exhibit skeletal muscle damage that is associated with chronic 
inflammation, numerous centrally nucleated fibers, and continuous cycles of myofiber degeneration/necrosis and regeneration. In particular, Duchenne muscular dystrophy (DMD) is a severe X-linked muscle disease in which mutations in the gene encoding the cytoskeletal protein dystrophin result in destruction of the dystrophinglycoprotein complexes of the sarcolemma ${ }^{31,32)}$. The resulting alterations in mechanical and signaling functions contribute to membrane fragility, necrosis, and immune cell infiltration, and cause progressive degeneration of striated muscle. The pathology of DMD muscles leads to chronic inflammation, fibrosis, fat infiltration, and impaired vasoregulation, manifesting as muscle weakness and eventually skeletal muscle atrophy ${ }^{33,34)}$. As the disease progresses, wheelchairs and ventilatory assistance are required, and patients often succumb to cardiac dysfunction and respiratory failure ${ }^{35)}$.

Cell-based therapies for DMD have the potential to restore dystrophin expression and, therefore, also the parenchyma of muscle. The following section introduces the general concepts behind gene- and cell-based strategies to treat DMD. Transplantation of mesoangioblasts, hematopoietic stem cells, myoblasts, and muscle-derived stem cells has been examined as a possible strategy to treat DMD and as a system to deliver therapeutic recombinant proteins to target muscle tissues ${ }^{36-38)}$.

In dystrophin-deficient $m d x$ mice, transplanted human MSCs were incorporated into myofibers and dystrophin expression was subsequently restored ${ }^{22,39,40)}$. MSCs transduced with Notch1 and treated with trophic factors and cytokines can differentiate when transplanted into the degenerated muscles of rats and $m d x$-nude mice. The induced population contains $\mathrm{Pax} 7^{+}$cells that contribute to the subsequent regeneration of muscles ${ }^{22}$. Transplantation of human adipose-derived MSCs transduced with a MyoD-coding lentiviral vector into the injured muscles of immunodepressed Rag2 ${ }^{-1} \mathrm{YC}^{-/}$mice resulted in a substantial increase in the number of myofibers and restoration of dystrophic expression ${ }^{41)}$. Although the engraftment of human MSCs from bone-marrow is improved in the presence of Pax3, supported by an approximately 1.3-fold increase in the level of myofibers in immunodepressed $\mathrm{mdx}$ mice, this engraftment is not accompanied by functional recovery $^{27}$.

In therapeutic approaches using medium-sized animal models of DMD, such as dogs, transplantation of heterologous mesoangioblasts in golden retriever muscular

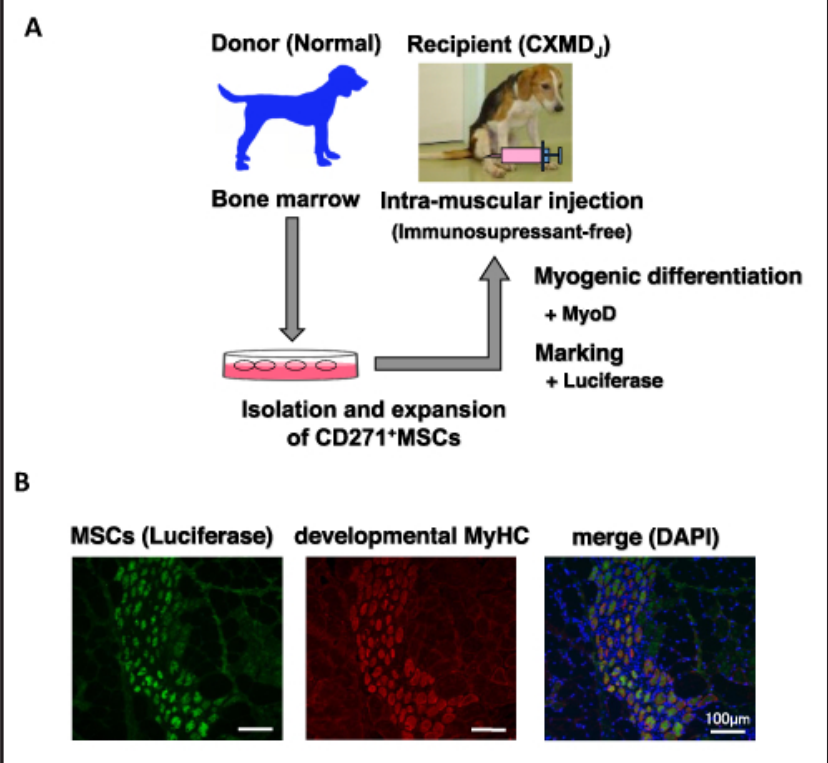

Fig.1 Successful long-term engraftment and myogenic differentiation of $\mathrm{CD} 271^{+} \mathrm{MSCs}$

(A) Transplantation procedure. CD271 ${ }^{+}$mesenchymal stem cells (MSCs) were enriched from the bone-marrow of healthy dogs and expanded. These cells were transduced with a luciferase-expressing lentivirus vector as a marker and a MyoD-expressing adenoviral vector, and injected into Duchenne muscular dystrophy dogs without immunosuppressants. (B) Engraftment and differentiation. At 12 weeks after $\mathrm{CD} 271^{+}$MSCs injection, cryosections from the muscle of recipients were stained with antibodies specific for luciferase expressed in MSCs (green) and the myogenic marker developmental myosin heavy chain ( $\mathrm{dMyHC}$ ) (red). The merged image includes staining of nuclei with 4', 6'-diamidino-2-phenylindole (DAPI) (blue). $\mathrm{CD} 271^{+}$MSCs formed muscle-like tissue that expressed dMyHC at 12 weeks after transplantation (Quote from ref. 21) with minor revision).

dystrophy (GRMD) ameliorated and preserved active motility ${ }^{42)}$. However, the development of an analogous approach for clinical use in humans has been hindered by the inability to overcome several obstacles, including poor cell survival rates, limited dissemination of injected cells, immune responses to allogeneic cells, the presence of the neotransgene product in dystrophic muscles, and the inability to specifically target the cells to particular regions, such as cardiac tissue ${ }^{43)}$.

In our previous study, we found that wild-type CD271 ${ }^{+}$ MSCs in a myogenic cell lineage transplanted into dogs with X-linked muscular dystrophy in Japan (CXMDJ) formed clusters of muscle-like tissues within 8-12 weeks in the absence of immunosuppression ${ }^{21)}$ (Fig.1). In the newly formed tissues, expression of developmental myosin heavy chain, which is a marker of myogenesis, and dystrophin 
was up-regulated. In CXMD, transplanted MSCs that are delivered systemically must specifically engraft into muscle tissue. MSCs normally mobilize in the blood in response to skeletal muscle injury ${ }^{44)}$, and several homing/migration/ engraftment studies have suggested that MSCs delivered systemically can "home" to the site of injury ${ }^{45-49)}$. Intraarterial injection of $\mathrm{CD} 271^{+} \mathrm{MSC}$ results in engraftment at the site of acutely injured muscle and the formation of muscle fibers $^{21)}$. These findings suggest that a cell transplantation strategy using $\mathrm{CD}_{2} 71^{+} \mathrm{MSC}$ is a promising treatment approach for DMD.

Human immature dental pulp stem cells (hIDPSCs), which are obtained from decidual tooth tissue and comprise a homogeneous population positive for MSC markers, are a more convenient cell source than bone-marrow. These cells are similar to populations of dental pulp MSCs with immunosuppressive activity ${ }^{50)}$. The proliferation and neurogenicity of hIDPSCs in dental pulp are more potent than those of bone-marrow MSCs, probably because the former cells are of neural crest origin. hIDPSCs inhibit the proliferation of phytohemagglutinin-stimulated T-cells, and therefore would elicit stronger effects than bone-marrow MSCs ${ }^{50,51)}$. After transplantation of hIDPSCs into young GRMD dogs without immunosuppression, a limited number of muscle fibers express dystrophin ${ }^{52}$.

These approaches using MSCs need to be further developed to obtain fully differentiated muscle fibers and to stimulate functional recovery of skeletal muscles in DMD patients.

\section{Therapeutic approach using the immuno- modulatory properties of MSCs}

MSCs regulate inflammation through mechanisms thought to involve the inhibition of monocyte differentiation into immature dendritic cells (DCs $)^{53)}$. This results in the skewing of DCs toward macrophages ${ }^{54,55)}$, suppression of DC maturation ${ }^{54,56)}$, inhibition of T-cell and B-cell proliferation, suppression of NK and cytotoxic T cell function ${ }^{57)}$, and inhibition of neutrophil apoptosis, inducing the generation of regulatory T-cells ${ }^{58)}$ (Fig.2). Therefore, the effects of MSCs on immune diseases have been investigated ${ }^{59,60)}$. Furthermore, interleukin (IL)-10-transfected MSCs can reduce the severity of acute GVHD and aid the recovery of cardiac function due to high levels of immunosuppression ${ }^{61,62)}$. Another study reported that human amniotic membranederived mesenchymal cells (hAMCs) markedly increase $H L A-G$ expression in vitro following administration of IL-10

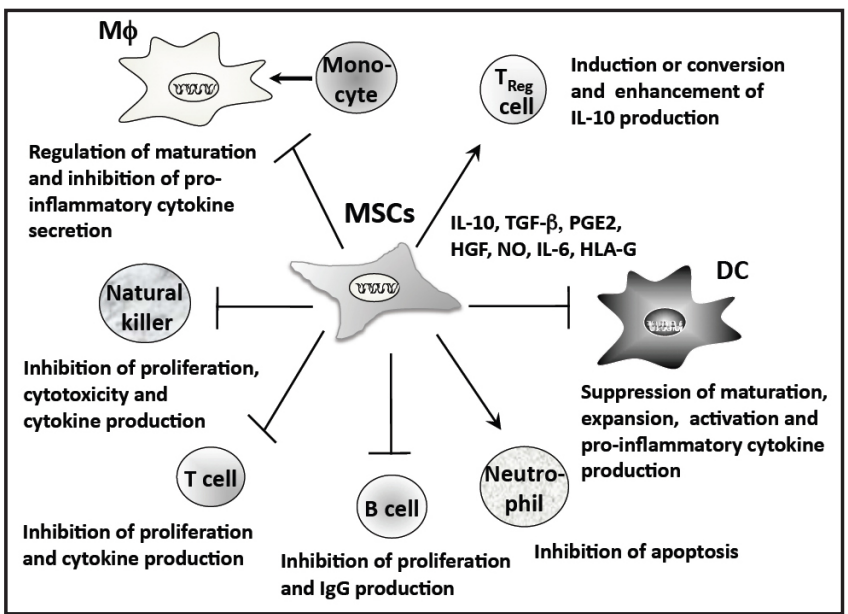

Fig.2 Immunoregulation by mesenchymal stems cells (MSCs) The immunoregulation of various cell types by MSCs through IL-10, TGF- $\beta$, PGE2, HGF, NO, and HLA-G is shown.

or progesterone, which plays an important role in fetomaternal tolerance during pregnancy, and, surprisingly, also increases the efficiency of cardiomyogenic transdifferentiation in vitro and in vivo ${ }^{63)}$. hAMCs have a great ability to transdifferentiate into cardiomyocytes and to acquire immunologic tolerance in vivo, and are, therefore, a promising source of allograftable stem cells for cardiac regenerative medicine ${ }^{63)}$.

In dystrophic muscles, activated immune cell infiltrates (e.g., T lymphocytes and macrophages) are observed during the early stages of disease and play a critical role in muscle wasting ${ }^{55-60)}$. Depletion or inhibition of these cells significantly improves dystrophic muscle pathology ${ }^{64-66)}$. The findings of these studies suggest that much of the muscle damage that occurs when dystrophin is deficient is caused by inflammatory cells, as well as by direct mechanical damage.

Inflammatory cytokines, serum markers, and intramuscular nuclear factor-kB are not upregulated in a $\delta$-sarcoglycandeficient dystrophic hamster model following intramuscular injection of human- and pig-derived MSCs. Additionally, transplantation of these MSCs is associated with the formation of new muscle fibers and reduced muscular oxidative stress ${ }^{67)}$. However, the majority of studies using MSCs in animal models do not report a significant, if any, increase in muscle contractile force ${ }^{27)}$. The therapeutic effects of MSCs are believed to not only be owing to their differentiation in injured tissue, but also to their production of paracrine factors that inhibit apoptosis of injected cells, induce anti-inflammatory effects, and stimulate the 


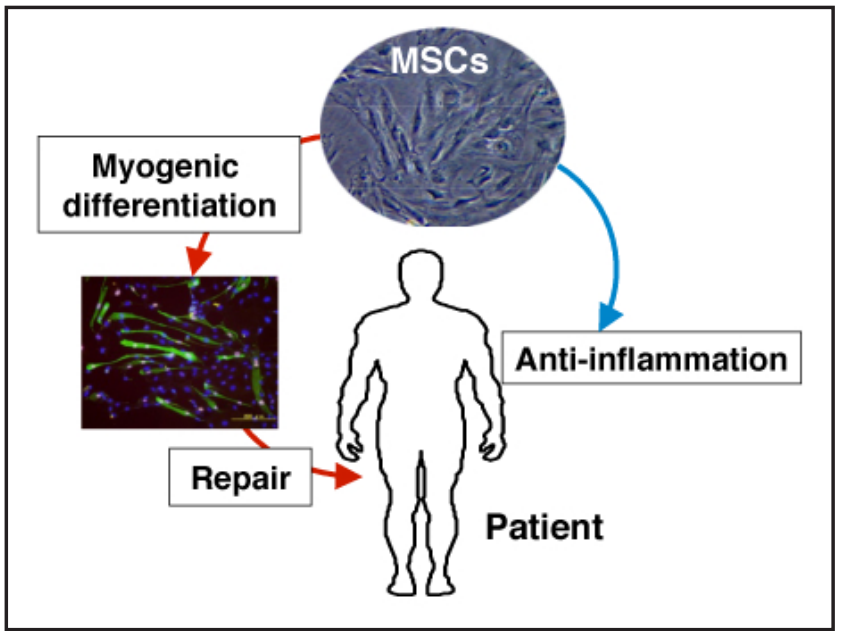

Fig.3 Cell-based therapeutic approach for muscular dystrophy An approach to treat DMD using MSCs is shown. MSCs undergo myogenic differentiation and thereby contribute to muscle repair, and also elicit anti-inflammatory effects.

proliferation of endogenous stem cells at the site of injury.

\section{Conclusion and future directions}

Clinical interest in MSCs for cell therapeutic applications is based on their anti-inflammatory properties and their ability to release cytokines into the surrounding environment, thereby modifying the developmental fate of neighboring cells. In this review, we introduced various strategies for the engraftment of transplanted cells as a therapeutic approach for muscular dystrophies. MSCs are a promising therapy for muscle disease because they elicit immunosuppressive and/or anti-inflammatory effects and can undergo myogenic differentiation contributing to muscle repair (Fig.3).

\section{Acknowledgements}

We thank our colleagues, laboratory members, and collaborators at JCR Pharmaceuticals Co., Ltd. for their excellent experimental assistance and simulating discussions.

\section{Sources of funding}

A grant-in-aid for scientific research (KAKENHI), a grant from the National Center for Child Health and Development (24-1), and a research grant from JCR Pharmaceuticals Co., Ltd.

\section{Disclosure of potential conflicts of interest}

We have received research support from JCR Pharmaceuticals Co., Ltd. and TaKaRa Bio Inc.

\section{References}

1) Friedenstein AJ, Petrakova KV, Kurolesova Al, Frolova GP: Heterotopic of bone marrow. Analysis of precursor cells for osteogenic and hematopoietic tissues. Transplantation. 1968; 6: 230-247.

2) Zannettino AC, Paton S, Arthur A, Khor F, Itescu S, Gimble JM, Gronthos S: Multipotential human adiposederived stromal stem cells exhibit a perivascular phenotype in vitro and in vivo. J Cell Physiol. 2008; 214: 413-421.

3) Hoogduijn MJ, Crop MJ, Peeters AM, Van Osch GJ, Balk AH, ljzermans JN, Weimar W, Baan CC: Human heart, spleen, and perirenal fat-derived mesenchymal stem cells have immunomodulatory capacities. Stem Cells Dev. 2007; 16: 597-604.

4) Chao KC, Chao KF, Fu YS, Liu SH: Islet-like clusters derived from mesenchymal stem cells in Wharton's Jelly of the human umbilical cord for transplantation to control type 1 diabetes. PLoS One. 2008; 3: e1451.

5) Jo YY, Lee HJ, Kook SY, Choung HW, Park JY, Chung $\mathrm{JH}$, Choung $\mathrm{YH}$, Kim ES, Yang HC, Choung PH: Isolation and characterization of postnatal stem cells from human dental tissues. Tissue Eng. 2007; 13: 767-773.

6) He Q, Wan C, Li G: Concise review: multipotent mesenchymal stromal cells in blood. Stem Cells. 2007; 25: 69-77.

7) Oh W, Kim DS, Yang YS, Lee JK: Immunological properties of umbilical cord blood-derived mesenchymal stromal cells. Cell Immunol. 2008; 251: 116-123.

8) Meng X, Ichim TE, Zhong J, Rogers A, Yin Z, Jackson J, Wang H, Ge W, Bogin V, Chan KW, Thebaud B, Riordan $\mathrm{NH}$ : Endometrial regenerative cells: a novel stem cell population. J Transl Med. 2007; 5: 57.

9) Hida N, Nishiyama N, Miyoshi S, Kira S, Segawa K, Uyama T, Mori T, Miyado K, Ikegami Y, Cui C, Kiyono T, Kyo S, Shimizu T, Okano T, Sakamoto M, Ogawa S, Umezawa A: Novel cardiac precursor-like cells from human menstrual blood-derived mesenchymal cells. Stem Cells. 2008; 26: 1695-1704.

10) Patel AN, Park E, Kuzman M, Benetti F, Silva FJ, Allickson JG: Multipotent menstrual blood stromal stem cells: isolation, characterization, and differentiation. Cell Transplant. 2008; 17: 303-311.

11) Jazedje T, Perin PM, Czeresnia CE, Maluf M, Halpern S, Secco M, Bueno DF, Vieira NM, Zucconi E, Zatz M: Human fallopian tube: a new source of multipotent 
adult mesenchymal stem cells discarded in surgical procedures. J Transl Med. 2009; 7: 46.

12)Bruder SP, Jaiswal N, Haynesworth SE: Growth kinetics, self-renewal, and the osteogenic potential of purified human mesenchymal stem cells during extensive subcultivation and following cryopreservation. J Cell Biochem. 1997; 64: 278-294.

13) Haynesworth SE, Goshima J, Goldberg VM, Caplan AI: Characterization of cells with osteogenic potential from human marrow. Bone. 1992; 13: 81-88.

14) Ju S, Teng GJ, Lu H, Jin J, Zhang Y, Zhang A, Ni Y: In vivo differentiation of magnetically labeled mesenchymal stem cells into hepatocytes for cell therapy to repair damaged liver. Invest Radiol. 2010; 45: 625-633.

15)Sun Y, Liu J, Qian F, Xu Q: Nitric oxide inhibits T cell adhesion and migration by down-regulation of beta1integrin expression in immunologically liver-injured mice. Int Immunopharmacol. 2006; 6: 616-626.

16)Kopen GC, Prockop DJ, Phinney DG: Marrow stromal cells migrate throughout forebrain and cerebellum, and they differentiate into astrocytes after injection into neonatal mouse brains. Proc Natl Acad Sci U S A. 1999; 96: 10711-10716.

17) Ma Y, Xu Y, Xiao Z, Yang W, Zhang C, Song E, Du Y, Li L: Reconstruction of chemically burned rat corneal surface by bone marrow-derived human mesenchymal stem cells. Stem Cells. 2006; 24: 315-321.

18)Caplan AI, Bruder SP: Mesenchymal stem cells: building blocks for molecular medicine in the $21 \mathrm{st}$ century. Trends Mol Med. 2001; 7: 259-264.

19) Nauta AJ, Fibbe WE: Immunomodulatory properties of mesenchymal stromal cells. Blood. 2007; 110: 3499-3506.

20) Rasmusson I, Ringden O, Sundberg B, Le Blanc $\mathrm{K}$ : Mesenchymal stem cells inhibit the formation of cytotoxic T lymphocytes, but not activated cytotoxic T lymphocytes or natural killer cells. Transplantation. 2003; 76: 1208-1213.

21) Nitahara-Kasahara $Y$, Hayashita-Kinoh $H$, OhshimaHosoyama S, Okada H, Wada-Maeda M, Nakamura A, Okada T, Takeda S: Long-term engraftment of multipotent mesenchymal stromal cells that differentiate to form myogenic cells in dogs with Duchenne muscular dystrophy. Mol Ther. 2012; 20: 168-177.

22)Dezawa $M$, Ishikawa $H$, Itokazu $Y$, Yoshihara $T$, Hoshino M, Takeda S, Ide C, Nabeshima Y: Bone marrow stromal cells generate muscle cells and repair muscle degeneration. Science. 2005; 309: 314-317.

23) Mizuno $\mathrm{H}$, Hyakusoku $\mathrm{H}$ : Mesengenic potential and future clinical perspective of human processed lipoaspirate cells. J Nippon Med Sch. 2003; 70: 300306.

24)Bai L, Lennon DP, Eaton V, Maier K, Caplan AI, Miller SD, Miller RH: Human bone marrow-derived mesenchymal stem cells induce Th2-polarized immune response and promote endogenous repair in animal models of multiple sclerosis. Glia. 2009; 57: 1192-1203.

25) Wise CJ, Watt DJ, Jones GE: Conversion of dermal fibroblasts to a myogenic lineage is induced by a soluble factor derived from myoblasts. J Cell Biochem. 1996; 61: 363-374.

26) Chan J, O'Donoghue K, de la Fuente J, Roberts IA, Kumar S, Morgan JE, Fisk NM: Human fetal mesenchymal stem cells as vehicles for gene delivery. Stem Cells. 2005; 23: 93-102.

27) Gang EJ, Darabi R, Bosnakovski D, Xu Z, Kamm KE, Kyba M, Perlingeiro RC: Engraftment of mesenchymal stem cells into dystrophin-deficient mice is not accompanied by functional recovery. Exp Cell Res. 2009; 315: 2624-2636.

28) Quirici N, Soligo D, Bossolasco P, Servida F, Lumini C, Deliliers GL: Isolation of bone marrow mesenchymal stem cells by anti-nerve growth factor receptor antibodies. Exp Hematol. 2002; 30: 783-791.

29) Chen L, Tredget EE, Wu PY, Wu Y: Paracrine factors of mesenchymal stem cells recruit macrophages and endothelial lineage cells and enhance wound healing. PLoS One. 2008; 3: e1886.

30) Burdzinska A, Gala K, Paczek L: Myogenic stem cells. Folia Histochem Cytobiol. 2008; 46: 401-412.

31) Moser $\mathrm{H}$ : Duchenne muscular dystrophy: pathogenetic aspects and genetic prevention. Hum Genet. 1984; 66: 17-40.

32) Koenig M, Hoffman EP, Bertelson CJ, Monaco AP, Feener C, Kunkel LM: Complete cloning of the Duchenne muscular dystrophy (DMD) cDNA and preliminary genomic organization of the DMD gene in normal and affected individuals. Cell. 1987; 50: 509-517.

33) Campbell KP: Three muscular dystrophies: loss of cytoskeleton-extracellular matrix linkage. Cell. 1995; 80: 675-679.

34) Ervasti JM, Ohlendieck K, Kahl SD, Gaver MG, Campbell KP: Deficiency of a glycoprotein component of the dystrophin complex in dystrophic muscle. Nature. 
1990; 345: 315-319.

35)Hahn A, Bach JR, Delaubier A, Renardel-Irani A, Guillou C, Rideau Y: Clinical implications of maximal respiratory pressure determinations for individuals with Duchenne muscular dystrophy. Arch Phys Med Rehabil. 1997; 78: 1-6.

36) Camargo FD, Green R, Capetanaki Y, Jackson KA, Goodell MA: Single hematopoietic stem cells generate skeletal muscle through myeloid intermediates. Nat Med. 2003; 9: 1520-1527.

37) Lee-Pullen TF, Bennett AL, Beilharz MW, Grounds MD, Sammels LM: Superior survival and proliferation after transplantation of myoblasts obtained from adult mice compared with neonatal mice. Transplantation. 2004; 78: 1172-1176.

38) Quenneville SP, Chapdelaine P, Rousseau J, Tremblay JP: Dystrophin expression in host muscle following transplantation of muscle precursor cells modified with the phiC31 integrase. Gene Ther. 2007; 14: 514-522.

39)Rodriguez AM, Pisani D, Dechesne CA, Turc-Carel C, Kurzenne JY, Wdziekonski B, Villageois A, Bagnis C, Breittmayer JP, Groux H, Ailhaud G, Dani C: Transplantation of a multipotent cell population from human adipose tissue induces dystrophin expression in the immunocompetent mdx mouse. J Exp Med. 2005; 201: 1397-1405.

40)De Bari C, Dell'Accio F, Vandenabeele F, Vermeesch JR, Raymackers JM, Luyten FP: Skeletal muscle repair by adult human mesenchymal stem cells from synovial membrane. J Cell Biol. 2003; 160: 909-918.

41) Goudenege S, Pisani DF, Wdziekonski B, Di Santo JP, Bagnis C, Dani C, Dechesne CA: Enhancement of myogenic and muscle repair capacities of human adipose-derived stem cells with forced expression of MyoD. Mol Ther. 2009; 17: 1064-1072.

42)Sampaolesi M, Blot S, D'Antona G, Granger N, Tonlorenzi R, Innocenzi A, Mognol P, Thibaud JL, Galvez BG, Barthelemy I, Perani L, Mantero S, Guttinger M, Pansarasa O, Rinaldi C, Cusella De Angelis MG, Torrente $\mathrm{Y}$, Bordignon C, Bottinelli R, Cossu G: Mesoangioblast stem cells ameliorate muscle function in dystrophic dogs. Nature. 2006; 444: 574-579.

43)Wang Z, Chamberlain JS, Tapscott SJ, Storb R: Gene therapy in large animal models of muscular dystrophy. ILAR J. 2009; 50: 187-198.

44)Ramirez M, Lucia A, Gomez-Gallego F, Esteve-Lanao
J, Perez-Martinez A, Foster C, Andreu AL, Martin MA, Madero L, Arenas J, Garcia-Castro J: Mobilisation of mesenchymal cells into blood in response to skeletal muscle injury. Br J Sports Med. 2006; 40: 719-722.

45)Koc ON, Gerson SL, Cooper BW, Dyhouse SM, Haynesworth SE, Caplan AI, Lazarus HM: Rapid hematopoietic recovery after coinfusion of autologousblood stem cells and culture-expanded marrow mesenchymal stem cells in advanced breast cancer patients receiving high-dose chemotherapy. J Clin Oncol. 2000; 18: 307-316.

46)Schenk S, Mal N, Finan A, Zhang M, Kiedrowski M, Popovic Z, McCarthy PM, Penn MS: Monocyte chemotactic protein-3 is a myocardial mesenchymal stem cell homing factor. Stem Cells. 2007; 25: 245-251.

47) Seeger FH, Zeiher AM, Dimmeler S: Cell-enhancement strategies for the treatment of ischemic heart disease. Nat Clin Pract Cardiovasc Med. 2007; 4 Suppl 1: S110-S113.

48) Shyu WC, Lee YJ, Liu DD, Lin SZ, Li H: Homing genes, cell therapy and stroke. Front Biosci. 2006; 11: 899-907.

49) Voermans C, van Hennik PB, van der Schoot CE: Homing of human hematopoietic stem and progenitor cells: new insights, new challenges? J Hematother Stem Cell Res. 2001; 10: 725-738.

50)Pierdomenico L, Bonsi L, Calvitti M, Rondelli D, Arpinati M, Chirumbolo G, Becchetti E, Marchionni C, Alviano F, Fossati V, Staffolani N, Franchina M, Grossi A, Bagnara GP: Multipotent mesenchymal stem cells with immunosuppressive activity can be easily isolated from dental pulp. Transplantation. 2005; 80: 836-842.

51)Di Nicola M, Carlo-Stella C, Magni M, Milanesi M, Longoni PD, Matteucci P, Grisanti S, Gianni AM: Human bone marrow stromal cells suppress T-lymphocyte proliferation induced by cellular or nonspecific mitogenic stimuli. Blood. 2002; 99: 3838-3843.

52) Kerkis I, Ambrosio CE, Kerkis A, Martins DS, Zucconi E, Fonseca SA, Cabral RM, Maranduba CM, Gaiad TP, Morini AC, Vieira NM, Brolio MP, Sant'Anna OA, Miglino MA, Zatz M: Early transplantation of human immature dental pulp stem cells from baby teeth to golden retriever muscular dystrophy (GRMD) dogs: Local or systemic? J Transl Med. 2008; 6: 35.

53) Newman RE, Yoo D, LeRoux MA, Danilkovitch- 
Miagkova A: Treatment of inflammatory diseases with mesenchymal stem cells. Inflamm Allergy Drug Targets. 2009; 8: 110-123.

54)Spaggiari GM, Abdelrazik H, Becchetti F, Moretta L: MSCs inhibit monocyte-derived DC maturation and function by selectively interfering with the generation of immature DCs: central role of MSC-derived prostaglandin E2. Blood. 2009; 113: 6576-6583.

55) Yang YW, Bai $H$, Wang $C B$, Lin M, Wu LQ: [Experimental study on influence of bone marrow mesenchymal stem cells on activation and function of mouse peritoneal macrophages]. Zhonghua Xue Ye Xue Za Zhi. 2008; 29: 540-543.

56)Chen L, Zhang W, Yue H, Han Q, Chen B, Shi M, Li J, Li B, You S, Shi Y, Zhao RC: Effects of human mesenchymal stem cells on the differentiation of dendritic cells from CD34+ cells. Stem Cells Dev. 2007; 16: 719-731.

57)Selmani Z, Naji A, Zidi I, Favier B, Gaiffe E, Obert L, Borg C, Saas P, Tiberghien P, Rouas-Freiss N, Carosella ED, Deschaseaux F: Human leukocyte antigen-G5 secretion by human mesenchymal stem cells is required to suppress $\mathrm{T}$ lymphocyte and natural killer function and to induce CD4+CD25 high FOXP3+ regulatory T cells. Stem Cells. 2008; 26: 212-222.

58)Casiraghi F, Azzollini N, Cassis P, Imberti B, Morigi M, Cugini D, Cavinato RA, Todeschini M, Solini S, Sonzogni A, Perico N, Remuzzi G, Noris M: Pretransplant infusion of mesenchymal stem cells prolongs the survival of a semiallogeneic heart transplant through the generation of regulatory T cells. J Immunol. 2008; 181: 3933-3946.

59)Le Blanc K, Rasmusson I, Sundberg B, Gotherstrom C, Hassan M, Uzunel M, Ringden O: Treatment of severe acute graft-versus-host disease with third party haploidentical mesenchymal stem cells. Lancet. 2004; 363: 1439-1441.

60)Fang B, Song YP, Liao LM, Han Q, Zhao RC: Treatment of severe therapy-resistant acute graft-versus- host disease with human adipose tissue-derived mesenchymal stem cells. Bone Marrow Transplant. 2006; 38: 389-390.

61) Holladay CA, Duffy AM, Chen X, Sefton MV, O'Brien TD, Pandit AS: Recovery of cardiac function mediated by MSC and interleukin-10 plasmid functionalised scaffold. Biomaterials. 2012; 33: 1303-1314.

62) Min CK, Kim BG, Park G, Cho B, Oh IH: IL-10-transduced bone marrow mesenchymal stem cells can attenuate the severity of acute graft-versus-host disease after experimental allogeneic stem cell transplantation. Bone Marrow Transplant. 2007; 39: 637-645.

63) Tsuji H, Miyoshi S, Ikegami Y, Hida N, Asada H, Togashi I, Suzuki J, Satake M, Nakamizo H, Tanaka M, Mori T, Segawa K, Nishiyama N, Inoue J, Makino $\mathrm{H}$, Miyado K, Ogawa S, Yoshimura Y, Umezawa A: Xenografted human amniotic membrane-derived mesenchymal stem cells are immunologically tolerated and transdifferentiated into cardiomyocytes. Circ Res. 2010; 106: 1613-1623.

64) Cai B, Spencer MJ, Nakamura G, Tseng-Ong L, Tidball JG: Eosinophilia of dystrophin-deficient muscle is promoted by perforin-mediated cytotoxicity by $\mathrm{T}$ cell effectors. Am J Pathol. 2000; 156: 1789-1796.

65) Hodgetts S, Radley H, Davies M, Grounds MD: Reduced necrosis of dystrophic muscle by depletion of host neutrophils, or blocking TNFalpha function with Etanercept in mdx mice. Neuromuscul Disord. 2006; 16: 591-602.

66) Radley HG, Grounds MD: Cromolyn administration (to block mast cell degranulation) reduces necrosis of dystrophic muscle in mdx mice. Neurobiol Dis. 2006; 23: 387-397.

67) Shabbir A, Zisa D, Leiker M, Johnston C, Lin H, Lee $\mathrm{T}$ : Muscular dystrophy therapy by nonautologous mesenchymal stem cells: muscle regeneration without immunosuppression and inflammation. Transplantation. 2009; 87: 1275-1282. 